\title{
HOW MAINSTREAM ECONOMISTS EXPLAIN (OR NOT) UNEMPLOYMENT?
}

\author{
MICHEL HUSSON ${ }^{1}$ \\ ${ }^{1}$ IRES (Institut de Recherches Economiques et Sociales), 16, boulevard du Mont d'Est, 93192 Noisy-le- \\ -Grand Cedex, France. ORCID: 0000-0003-3284-7049, Email: michel.husson@ires.fr
}

\begin{abstract}
One of the tasks assigned to mainstream economists is to legitimize the significance of unemployment. This paper aims to reconstruct the evolution of their approaches from the theoretical impossibility asserted by Pigou to the recognition of involuntary unemployment by Keynes and eventually to different versions of the natural unemployment rate. The unemployment rate had become an instrument for fine-tuning of the economy, but it no longer fulfills this role. It is then the whole dominant macroeconomics that is shaken to its foundations. But this crisis might help to return to expansionary fiscal policies (a Green New Deal) and to the Job Guarantee, thus echoing Keynes' question: 'There is work to do; there are men to do it. Why not bring them together?'

KEYWORDS: unemployment, mainstream economics, The Phillips curve, NAIRU, Keynesian economics
\end{abstract}

One of the tasks assigned to mainstream economists is to legitimize the significance of unemployment. For a long time, unemployment was considered as a theoretical impossibility and, in practice, a necessary evil, or the result of excessively high wages. It was not until Keynes that the hypothesis of involuntary unemployment was considered. The monetarist counter-revolution suggested a return to traditional sources and then was established a synthesis that made the unemployment rate an instrument for tuning the economy. Finally, the consequences of the recent crisis are leading to a slow implosion of the dominant pattern. This paper aims to capture the key moments of this trajectory. 


\section{IMPOSSIBLE IN THEORY, INELUCTABLE IN PRACTICE}

For a long time, economists have not been concerned about full employment. The term 'unemployment' itself is nearly absent from the treaties by Alfred Marshall who, for many decades, was the leading economist in England. Marshall's views have remained those of the authors of the famous Poor Law Report of 1834 (see Husson 2018a), as evidenced in a letter sent in 1903 to Percy Alden, in which Marshall expresses the substance of his thinking (Marshall 1903). There are, he writes, two categories of unemployment: the occasional unemployment results from economic fluctuations, but only develops because of 'the inability of beings of finite intelligence to forecast coming economic needs and opportunities with perfect precision' (Marshall 1903: 446). They should therefore be taught that 'to spend the whole of one's income in prosperous times and to be without resource when the tide turns, is inconsistent with the respect that everyone owes to himself' (Marshall 1903: 446). As for the systematic unemployment, Marshall believes that it is:

(...) caused by the existence of large numbers of people, who will not or cannot work steadily or strongly enough to make it possible that they should be employed regularly. They are hunters for odd jobs, which are generally 'soft' jobs. A large part of the present unemployment seems to me to be this kind: that is, it is a symptom of disease rather than a cause. And remedies addressed to the symptoms of it are likely, I fear, to increase the disease. (Marshall 1903: 446)

Marshall calls for a 'kindly but severe discipline of those who are bringing up children under physical and moral conditions which will make them recruits to the great army of the habitually unemployed' (Marshall 1903: 447).

The discourse of economists will gradually incorporate a less moralistic yet implacable analysis. In the perfect world of free competition, unemployment cannot exist, or might exist only in the form of 'voluntary' unemployment resulting from a rational trade-off between wages and leisure. Their main advice is therefore to recommend the removal of all obstacles to the balance between supply and demand in the labour market. This market is not fundamentally different from any other commodity, be it a potato or a sock.

As for the term 'full employment', it is sometimes argued that it first appeared under the pen of Arthur Pigou (1877-1959) - a disciple of Marshall - in his book Unemployment, published in 1913. It happens to be a misinterpretation, because Pigou uses the term of full employment in a different sense, which refers to the full-time employment of certain categories of workers. However, Pigou's book is interesting as it presents very clearly an approach to the issue of unemployment, which then remains largely dominant. Its basic principle is that 'unemployment is wholly caused by maladjustment between wage-rates and demand' (p. 51).

Therefore, if wages 'were determined by the free play of competitive forces (...) there could not exist any unemployment whatever' (p. 51-52), beyond cyclical fluctuations. In particular, 'any attempt on the part of a particular Trade Union to force up the wages of its members above those current in the general run of similar occupations is 
a cause of unemployment, and the abandonment of that policy is, pro tanto, a remedy for it' (p. 242).

The instruments to reduce unemployment inevitably have adverse effects. Public employment excludes - as we would say today - private employment. Pigou cites, in this regard, a report by the commission on South African poverty (Transvaal Indigency Commission). The reference is curious, but the statement is very clear:

When, therefore, a Government gives work to the unemployed (...) it is diminishing employment with one hand, while it increases it with the other. It takes work from people employed by private individuals, and gives it to people selected by the State (Pigou 1913: 171).

Finally, there is - already - the perennial denunciation of the minimum wage:

When humanitarian considerations lead, in effect, to the establishment of a minimum wage below which no worker will be engaged, the existence of a large body of persons not worth this minimum wage is a cause of unemployment (Pigou 1913: 242-243).

However, even if all the recommendations were implemented, this would not be sufficient to 'abolish unemployment' and therefore it is necessary to use 'palliatives' such as unemployment insurance scheme. In other words, unemployment is an inseparable attribute of a market economy: we can only limit its scope and 'alleviate the evil consequences' (p. 246).

The term 'full employment' is generally associated with the name of William Beveridge (1879-1963). It is interesting to look back at his first contribution in his book Unemployment. A Problem of Industry, published in 1909, favourably cited by Pigou. Beveridge considers there that 'unemployment is to some extent at least part of the price of industrial competition' (p. 235). The appropriate answer is in practice 'reducing the pain of unemployment to relative insignificance' (p. 235). So it is rather a theory of 'frictional' unemployment and we are still far from the full employment of which Beveridge will later be one of the most active promoters.

It is important to note that economic theories are not impervious to the economic situation that sometimes provides concrete demonstrations. A fine example is given by John Hobson, a heterodox economist made famous by his analyses of imperialism - and who can also be considered as a precursor of Keynes for his work on unemployment. In his book Problems of poverty, published in 1899, he pointed out that:

(...) the fact that in 1890 the mass of unemployed was almost absorbed, disposes once for all of the allegation that the unemployed in times of depression consist of idlers who do not choose to work (Hobson 1899: 16).

However, the prosperity recorded during the 'Belle Époque', from 1896 to 1924, allowed observers to be satisfied with unemployment analyses as the result of transitional misadjustments. It was the great crisis of 1929 that made these representations shatter. 


\section{KEYNES DISCOVERS INVOLUNTARY UNEMPLOYMENT}

It was in 1929 that an economist proposed a radical change of point of view: 'the belief that that there is some law of nature which prevents men from being employed, that it is "rash" to employ men, and that it is financially "sound" to maintain a tenth of the population in idleness for an indefinite period, is crazily improbable - the sort of thing which no man could believe who had not had his head fuddled with nonsense for years and years' (p. 10).

And the same economist puts forward a simple reasoning, which some would certainly describe as simplistic. This economist is none other than John Maynard Keynes who signed along with Hubert Henderson a brochure entitled Can Lloyd George Do It? It contains what could be the guiding theme of this contribution:

The whole of the labour of the unemployed is available to increase the national wealth. It is crazy to believe that we shall ruin ourselves financially by trying to find means for using it and that 'Safety First' lies in continuing to maintain men in idleness (Keynes Henderson 1929: 38).

Therefore, Keynes encourages us to a major reversal which consists in returning to a rational approach and even to the 'common sense'. He also reassures his readers on this point: 'what seems sensible is sensible, and what seems nonsense is nonsense' ( $p$. 11).

Nor should we be frightened by the bogeyman which, even today, is still used by the advocates of 'natural' unemployment:

The conclusion, that if new forms of employment are offered more men will be employed, is as obvious as it sounds and contains no hidden snags; that to set unemployed men to work on useful tasks does what it appears to do, namely, increases the national wealth; and that the notion, that we shall, for intricate reasons, ruin ourselves financially if we 'use' this means to increase our well-being, is what it looks like a bogy (Keynes Henderson 1929: 11).

Keynes is also not satisfied with the safety net provided by the benefits paid to the unemployed, because these benefits do not create anything. In his opinion, true security is 'an honest day's work for a fair wage waiting for every honest worker', as he writes in his notes. And full employment (even if he does not use this term) is not 5\% unemployed: unemployment must be reduced: 'to the sort of level we are experiencing in wartime, that is to say (...) less than one per cent unemployed at the present time'. For this to happen, the State must do 'everything that could humanly be done'. And Keynes expresses his indignation: 'It is crazy to sit puffing one's pipe and telling the unemployed that it would be most unsafe to find them any work' (Tcherneva 2012 for these last quotes).

It is therefore logical that Keynes declared himself in favor of large-scale public works programs and paid little attention to their rate of return: the important thing being to reduce unemployment, it is better to have a low return than no return at all. These suggestions were caricatured by assigning to him the idea that the unemployed should be employed to dig holes and then fill them up. That's probably the risk of be- 
ing too subtle, because Keynes never said that. In the General Theory, he imagines that the government buries bottles filled with banknotes for the unemployed to dig them up. But it was a parable on money creation, drawing a parallel with gold mines where holes are also dug.

Even before the publication of the General Theory in 1936, some of Keynes' 'common sense' ideas were implemented in the United States by Franklin Roosevelt, as part of the New Deal. He was elected after the catastrophic presidency of Herbert Hoover, who saw the prosperity 'just around the corner'. When Roosevelt came to power, there were 12 million unemployed, for a working population of about 50 million, to which must be added several million homeless. While the previous administration merely distributed aid, this time the objective was to create jobs. One of the program's administrators, Harry L. Hopkins, could justify this changeover as follows:

Give a man a dole and you save his body and destroy his spirit. Give him a job and pay him an assured wage, and you save both the body and the spirit (Hopkins 1936 quotes by Bremer 1975: 637).

It was therefore a vast public works program that was launched in 1933 with the establishment of the Public Works Administration associated with a Civilian Conservation Corps and, in 1935, the Works Projects Administration. All the said programs will not restore full employment and will reduce unemployment by only about one-third. The record of the New Deal that can be only outlined here is indeed mixed. Roosevelt's plans were obstructed by businesses' investment strike that the public initiative could not counterbalance. There were still six million Americans unemployed in 1941, and full employment was not restored until the entry into the war.

The post-war period will be marked by the development of the welfare state in $\mathrm{Eu}$ rope, one of the fathers of which is William Beveridge, the author of two famous reports. The first report, published in 1942, dealt with social security; the second, dating from 1944, with Full Employment in a Free Society. In the prologue to this report, Beveridge immediately points out that full employment 'does not mean having no unemployment at all' but 'having more vacancies for workers than there are workers seeking vacancies' (p.1). There will therefore still remain a frictional unemployment rate, which he estimates at $5 \%$ of the working population in the case of the United Kingdom.

\section{THE PHILLIPS CURVE, OR THE FINE TUNING OF UNEMPLOYMENT}

In 1958, Alban Phillips (see Husson 2018b for a short biography) published an article (Phillips 1958) that earned him fame, since we are still talking about Phillips curve today. His article states that nominal wage growth is moving in the opposite direction to the unemployment rate (and its changes). Phillips' data focus on the long-term evolution of unemployment and wages in the United Kingdom, between 1861 and 1957. When the article was published in 1958, the nominal wage growth rate was indeed quite high, but the country was close to full employment: the unemployment rate had been around $2 \%$ since 1945 . Phillips' project therefore does not address a contem- 
porary economic problem. His project is substantially different: its aim is to provide the empirical basis for unemployment theory. But how should the curve be read? For Richard Lipsey, a colleague of Phillips' who is trying to find a more theoretical basis for the curve, the determination clearly goes from unemployment to wages:

If one wishes to predict the rate of change of money wage rates, it is necessary to know not only the level of unemployment but also its distribution between the various markets of the economy (Lipsey 1960: 19).

A reverse reading will be proposed by Paul Samuelson and Robert Solow in an article published in 1960 (Samuelson, Solow 1960). The two future Nobel Prize winners are trying to create a Phillips curve for the United States - which eventually is hand-drawn. They suggest a reading of the curve where it is the unemployment rate that determines wages: the latter 'tend to rise when the labor market is tight, and the tighter the faster' (p.189). But most importantly, they deduce from this that there is a possible trade-off between moderate inflation and an unemployment rate close to full employment:

Manufacturing wages seem to stabilize absolutely when 4 or 5 per cent of the labor force is unemployed; and wage increases equal to the productivity increase of 2 to 3 per cent per year is the normal pattern at about 3 per cent unemployment (Samuelson Solow 1960: 189).

The Phillips curve then became a fine tuning instrument for economic policy during the 1960s, when Keynesian ideas influenced the Kennedy and Johnson administrations in favour of an expansive fiscal policy.

This worked well until the late 1960s: the inflation and unemployment curves did indeed change in the opposite direction. But this relationship corresponding to Phillips curve breaks down twice: first with the 1967 recession (when the profit rate begins to fall in the United States) and then with the 1974-75 (global) recession. This marks the beginning of the so-called 'stagflation' period, when inflation and unemployment rise together: it will last until the mid-1980s (Figure 1). 
Figure 1. Inflation and unemployment in the United States 1950-2016

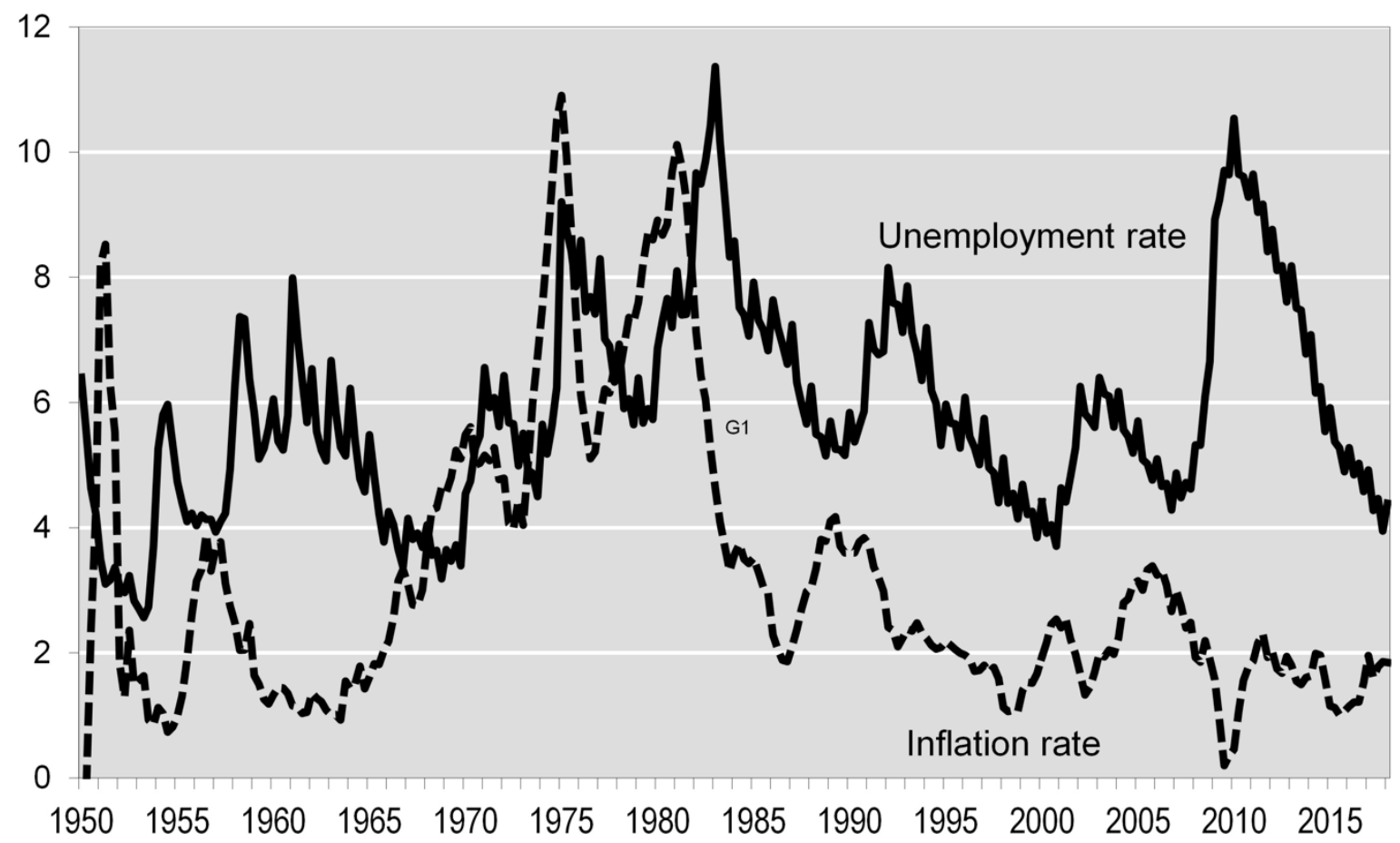

Source: FRED (Federal Reserve Economic Data), Federal Reserve Bank of St. Louis.

\section{STAGFLATION AND FAILURE OF KEYNESIANS}

Milton Friedman began the offensive in 1967 in his address to the assembly of the American Economic Association (Friedman 1968). But it is in his Nobel Prize acceptance speech (Friedman 1977) that he delivers the clearest account. He begins by evoking the passage from the General Theory where Keynes admits that an equation is missing:

Therefore we cannot say what aggregate employment will be, until we know the money-price of wage-goods; and we cannot know the money-price of wagegoods until we know the aggregate amount of employment. We are, as I have said, one equation short (Keynes 1936: 276).

The Phillips curve has reportedly filled this gap. 'In addition, it seemed to provide a reliable tool for economic policy, enabling the economist to inform the policymaker about the alternatives available to him' (Friedman 1977: 469).

But, over time, it became clear that there was a need for 'larger and larger doses of inflation to keep down the level of unemployment. Stagflation reared its ugly head' (p. 469). Friedman's criticism could then be summarized as follows: Phillips curve was received by Keynesians as the missing piece of their model. It established the possibility of a trade-off between unemployment and inflation rates, but only if the longterm stability of the Phillips curve was assumed. On this basis, Keynesians inspired policies of full employment that proved inflationary. The appearance of stagflation in the 1970s is related to the correction of expectations because the Phillips curve is not stable, contrary to the Keynesian assumption (Rubin 2012). 
The concept of expectations plays a key role here: the idea is that if we accept a certain acceleration in inflation, the 'agents' will expect a continuation of the movement, and the Phillips curve will move. This is what policymakers who stuck at the basic Phillips curve did not presumably understood:

Gaps between a true expectational Phillips curve and the monetary authority's approximating nonexpectational Phillips curve models unleash inflation that a monetary authority that knows the true model would avoid (Sargent, Williams, Zha 2006: 1193).

Two economists from the National Bank of Belgium have recently reproduced this criticism (Cordemans, Wauters 2018). In their opinion, the view that one can 'choose given inflation and unemployment rates by stimulating or restraining aggregate demand' is wrong (p. 87). This can only work in the short term and the notion of expectations is again used:

The central bank cannot continuously keep the unemployment rate below its natural level. The resulting pressures would constantly push inflation expectations and real inflation up, and the unemployment rate would systematically return to its natural level. This would ultimately lead to higher inflation, but would not be accompanied by a lower unemployment rate (Cordemans, Wauters 2018: 87).

The denial of the Keynesian paradigm made by stagflation thus opens the way to a real counter-revolution. One of the fiercest opponents of Keynesianism is Robert Lucas, who goes so far as to challenge the notion of involuntary unemployment. It would be an eccentric idea of Keynes:

Involuntary unemployment is not a fact or a phenomenon which it is the task of theorists to explain. It is, on the contrary, a theoretical construct which Keynes introduced in the hope that it would be helpful in discovering a correct explanation for a genuine phenomenon: large-scale fluctuations in measured, total unemployment (Lucas 1978: 354).

As a result, the very notion of full employment disappears:

It does not appear possible, even in principle, to classify individual unemployed people as either voluntarily or involuntarily unemployed depending on the characteristics of the decision problems they face. One cannot, even conceptually, arrive at a usable definition of full employment as a state in which no involuntary unemployment exists (Lucas 1978: 355).

In a very controversial way, Lucas wants the modern theoretical economy to no longer waste its time with the 'theoretical constructs of our predecessors' (that is Keynes'), which is the surest way 'to sterility' (p. 355).

This monetarist offensive anticipated the neo-liberal counterrevolution. They advocate the neutralization of monetary policy reduced to a rule of stable growth of the money supply. As for unemployment, it must be combated by making the labor market more flexible and removing its structural rigidities. There is no need to underline that 
what we see here is the neo-liberal doxa emerging: central bank independence and structural reforms.

\section{AN IMPOSSIBLE SYNTHESIS: THE MCCRACKEN REPORT}

The McCracken report published by the OECD in June 1977 has a significant title: Towards full employment and price stability (McCracken 1977) and marks a double watershed. It comes just after the worldwide recession of 1974-75, which marked the end of the 'golden age', and at the height of the neo-liberal offensive against Keynesianism. The opposition between these two schools of thought is crystallized, as Vincent Gayon shows, 'on one of the central instruments of post-war macroeconomic policies used in most OECD member countries: the Phillips curve' (Gayon 2017: 136).

However, the report remains at a crossroads and reveals a certain confusion, because, as its leader admits: 'we didn't know what idea we wanted to produce' (quoted by Gayon 2017). Robert Lucas, one of the most virulent anti-Keynesians, when talking about this report describes it as 'undisciplined eclecticism' and 'opportunism posing as pragmatism' (Lucas 1979: 163).

\section{THE NAIRU, OR UNEMPLOYMENT IN EQUATIONS}

Since the neo-liberal turn of the 1980s, a new conception of unemployment gained ground: it explains why full employment is neither possible nor desirable. Fundamentally, this theory, which is dominant today, is based on a reformulation of the trade-off between inflation and unemployment. There is an unemployment rate below which inflation increases, and this increase in inflation has recessive effects that bring it back to this incompressible level. It is known as 'Nairu' (Non-Accelerating Inflation Rate of Unemployment), structural, equilibrium or even 'natural' unemployment rate. Beyond lexical subtleties, all this refers to the same idea: a smooth functioning of capitalism requires a certain amount of unemployment that cannot be reduced without negative effects on economic activity. One could say that the Phillips curve is reversed: it is no longer inflation that regulates unemployment, but it is unemployment that is used to contain inflation.

The concept of Nairu was introduced in 1975 by Franco Modigliani and Lucas Papademos (1975), two more or less Keynesian economists, who sought to soften Milton Friedman's concept of the natural unemployment rate. More precisely, they call it NIRU (non-inflationary unemployment rate). It was James Tobin who introduced the term Nairu in 1980, even though he said a few years earlier that: 'The Phillips curve has been an empirical finding in search of a theory, like Pirandello characters in search of an author' (Tobin 1972: 9). No doubt it was finally found...

This scientifically calculated equilibrium unemployment dogma led to Robert Solow's bitter comments at the end of a conference marked by the anti-Keynesian offensive made by Lucas and Sargent. Many contemporary economists should meditate on these remarks:

You have to have a very good reason for believing that the natural unemploy- 
ment rate is $51 / 2$ percent if you want to go out and face all those people who are unemployed. It is no joke. For statisticians it is just numbers, just something that comes out when you set something equal to zero and divide one number by another. But those fellows out there are not working. You ought to be sure of what you are talking about, and that the right figure is $51 / 2$ percent and not $31 / 2$ or 4 $1 / 2$ percent before you pretend that it has some relevance to practical life (Solow 1978: 207).

This new concept has given rise to a considerable volume of byzantine theoretical discussions, but also to many - and futile - attempts to evaluate the famous Nairu in a stable and consensual manner. The reader will not have to deal with the details, but rather with the hidden side of this theoretical montage.

\section{UNDER INFLATION, PROFIT}

It should be noted first of all that Nairu only repeats, in its own way, Marx's analysis of the role of unemployment on wage trends:

The general movements of wages are exclusively regulated by the expansion and contraction of the industrial reserve army, and this in turn corresponds to the periodic alternations of the industrial cycle. They are not therefore determined by the variations of the absolute numbers of the working population, but by the varying proportions in which the working class is divided into an active army and a reserve army, by the increase or diminution in the relative amount of the surplus population, by the extent to which it is alternately absorbed and set free (Marx 1976: 790).

With Nairu, it is a question of navigating as well as possible between Charybdis (inflation) and Scylla (unemployment). But behind inflation, there are wages and, as a result, profit. From this point of view, the OECD and the European Commission are more explicit and calculate Nawru, i.e. the Non accelerating Wage Rate of Unemployment. This makes things clearer, because it is a trade-off between wages and profit that is actually in question. As Patrick Artus (a very erratic Marxist) reminds us excellently, you should never:

(...) forget that inflation occurs when profitability of businesses is below the desired level. [It] results from the willingness of companies to restore their profitability if it is below the level they wish (Artus 2018b).

This is the key to another explanation of stagflation in the United States that does not use anticipations and other monetarist lucubrations: it is sufficient to observe the profit rate (Figure 2). Until the 1967 recession, it fluctuated at a high level: this is also, as we have seen, the period when the Phillips curve works. But it is clear that the decline in the profit rate from 1967 to the early 1980s was accompanied by an accelerating inflation. The shock of neo-liberal policies triggered, simultaneously, the rise in the profit rate and the return of the inflation rate to its 1960s level. The real trade-off is therefore between inflation (read: wages) and profit, and the unemployment rate is 
the tool to settle this trade-off.

Figure 2. Profit and inflation in the United States 1950-2016

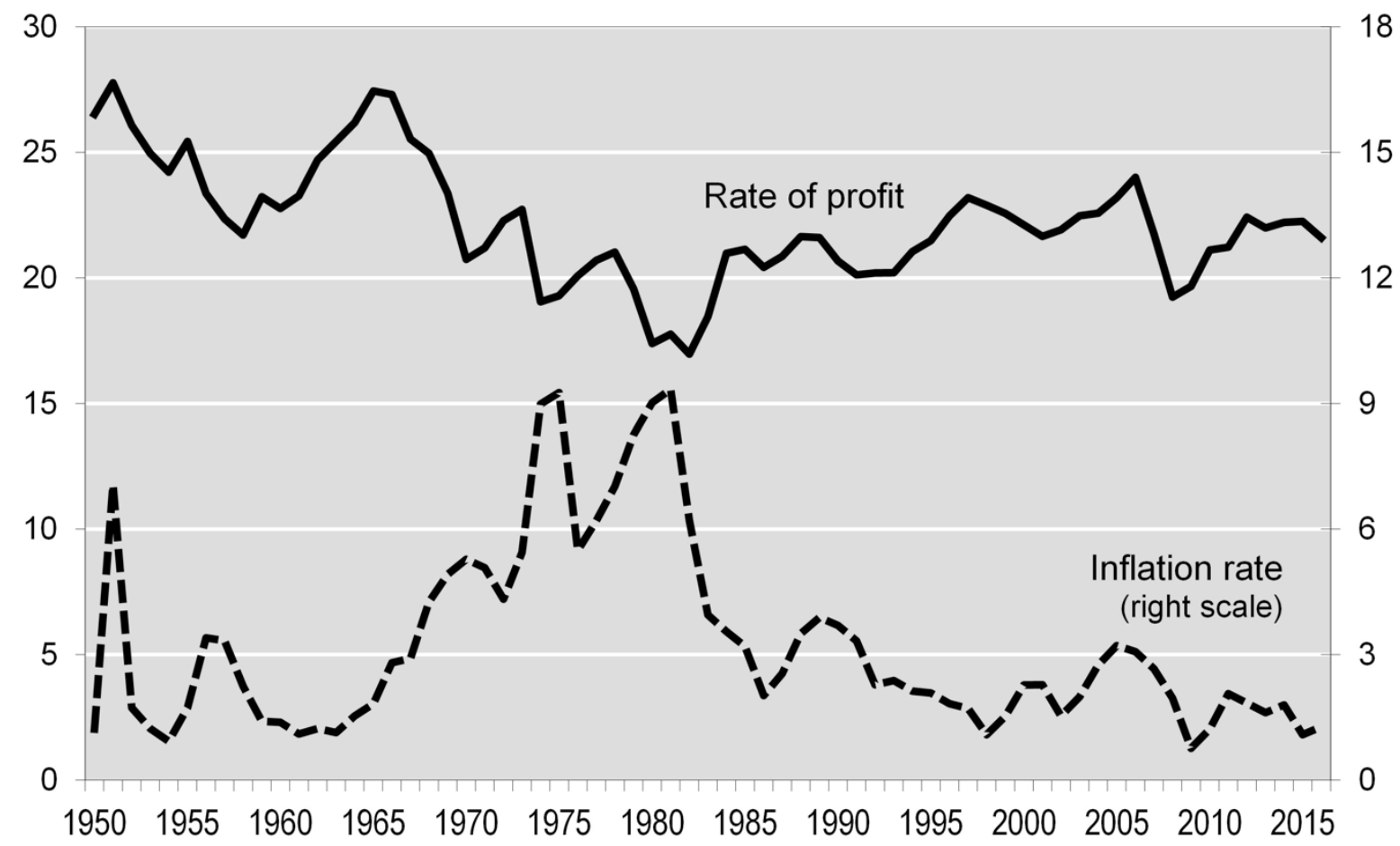

Source: BEA (Bureau of Economic Analysis)

The pattern is therefore as follows: if the unemployment rate falls too much, the balance of power between capital and labor changes in favor of employees. Wage increases bite into profit and companies respond by increasing their prices. The unemployment rate that does not accelerate inflation could, just as well and this would be clearer, be called 'unemployment rate that the profit rate does not decrease'.

Behind the mathematical apparatus, the main means can be found in the method used to calculate the Nairu (see appendix). The price equation says that the latter is formed by applying the mark-up on cost to the unit wage cost. The whole skill is to discreetly postulate that this mark-up on cost, which is nothing more than the share of profit in value added, is somehow untouchable. It only takes one sentence for Layard, Nickell and Jackman - the authors of the classic Unemployment (1991) - to dismiss this detail: 'Prices (of value added) are set as a mark-up on expected wages. The mark-up tends to rise with the level of activity although this effect may not be very strong' (Layard, Nickell, Jackman 1991: 13).

The sleight of hand is quite successful. It is this small detail of specification that makes it possible to replace the issue of the sharing between wages and profit by a trade-off between unemployment and inflation. All that must be done then is to discreetly assume that the mark-up on cost is fixed, in other words that the wages/profit sharing is immutable.

The Nairu theory therefore amounts to fetishizing unemployment as an instrument for tuning the economy. As full employment is out of reach, it can no longer be part of the political agenda. Governments are somehow relieved of any responsibility for 
employment:

One of the serious unintended consequences of economists' preoccupation with NAIRU has been to convey a message to political leaders that they need not feel any responsibility in this area, that the inflation-unemployment trade-off can be fine-tuned with interest rates by the Fed. It isn't so (Galbraith 1997: 106).

Unemployment is no longer a social phenomenon but one of the cogs of the great economic machinery.

\section{BYE BYE, PHILLIPS?}

There is a heated debate among economists today as to whether or not the Phillips curve continues to work. Indeed, the unemployment rate is falling in several countries and we are thus getting closer to full employment, at least as defined by these economists. And yet, neither wages nor inflation are restarting. Most recently, the OECD (2018) has noted with concern that there is a 'rising employment overshadowed by unprecedented wage stagnation'.

Some, such as the IMF (2017), propose adjustments, others argue that the famous curve is still valid even if it has flattened (Blanchard 2016) or on the contrary that it has disappeared. The economists from the Banque de France want to reassure themselves:

Estimates from the Banque de France show that the slope of the Phillips curve in the euro area has remained weak but stable and significantly different from zero since the crisis (Berson et al. 2018: 1).

But they remain doubtful:

However, our estimates of the Phillips curve remain uncertain. We must remain attentive to all the determinants of inflation and, in particular, to the structural changes in the economy (Berson et al. 2018: 4).

Two economists (McLeay, Tenreyro 2018: 2) go so far as to argue that the fact that it is difficult to empirically identify the Phillips curve does not imply that it does not work. Its disappearance 'is a result to be expected when monetary policy is set optimally' (2018: 2). It is therefore the action of the Central Bank (aware of the existence of the curve) that leads to its disappearance. Finally, Patrick Artus (2018a) notes that 'the Phillips curve is upside down'.

In short, the Phillips curve moves, reverses, disappears or remains invisible: we are in the middle of magical thinking. This debate provides a fairly good illustration of the excesses of academic economics. Robert Solow was right to say that Phillips' article 'has provided more employment than any project since the construction of the Erie Canal' (Solow 1979 quoted by Schwarzer 2015: XV).

And perhaps today we could repeat Mark Blaug's remark who described the 1960s debate between Keynesians and monetarists as 'one of the most frustrating and irritating controversies in the entire history of economic thought, frequently resembling medieval disputations at their worst' (Blaug 1980: 196). 


\section{NEO-LIBERAL DISARRAY}

Several reasons can be given to explain the flattening or disappearance of the Phillips curve. First, there is the idea, which applies well to France, according to which a modest decline from a high unemployment rate is no longer sufficient to reduce labour market tensions. Other factors may also play a role, such as the increase in the employment rate of older workers or the extension of precarious employment: in both cases, the categories of employees concerned are not in a position to demand wage increases. The IMF explains it in these terms:

While involuntary part-time employment may have helped support labor force participation and facilitated stronger engagement with the workplace than the alternative of unemployment, it also appears to have weakened wage growth (IMF 2017: 73).

Finally, structural reforms, the decline in union density and in industrial employment, which probably go hand in hand, are working in the same direction. All this contributes to the fact that the unemployment rate as such is no longer an indicator of the balance of power between capital and labour, nor is it an adequate measure of the dynamism of labour markets.

This disarray of economists has another explanation than econometric disappointments: the erasure of the Phillips curve undermines the dominant theoretical model. First, the classic explanation of natural unemployment, equilibrium unemployment, etc. no longer holds: if the fall in the unemployment rate is no longer matched by inflation, it is no longer possible to explain or legitimize its incompressible level.

And yet things are even more serious, because the adjustment of the economy is no longer possible. The basic model underlying neo-liberal discourse and practices involves three relationships:

- the Phillips curve or one of its substitutes: unemployment makes it possible to regulate essentially wage inflation;

- aggregate demand: it varies in the opposite direction to the real interest rate;

- the 'Taylor rule': when inflation exceeds the target, the central bank raises the interest rate and reduces or slows down demand and thus employment.

It is clear, then, that if the Phillips curve evaporates, this management model disappears. That's what Blanchard fears: Patrick Artus goes even further:

If these developments persist, the entire theoretical basis of euro area monetary policy (monetary pillar, reaction of interest rates to the unemployment rate or to the output gap, credibility) collapses and should therefore be replaced (Artus 2018c).

And it is a Financial Times journalist who best summarizes the situation: 'Remove the PC, and the central bankers are floundering' (Davies 2017). Ten years after the crisis broke out, the dominant economists note bitterly that their tools are no longer working. Their schemes claiming to be theoretical no longer have any control over the 
concrete functioning of capitalism and Patrick Artus, decidedly very lucid, admits that he no longer knows how to 'analyse the situation' (Artus 2017).

And it is quite surprising to note that it is The Economist (2017) which deplores the workers' lack of bargaining power. The Bible of intelligent neo-liberalism explains that 'If wages are to rise, workers need more bargaining power' and that 'historically, this has been most effectively done by bringing more workers into unions'. It's as if we were dreaming! But the conclusion of the article also sounds like a warning: 'More empowered workers would no doubt unnerve bosses. But a world in which pay rises are unimaginable is far scarier'.

\section{WHEN THE EUROPEAN CENTRAL BANK IS WADING THROUGH}

A recent example of this disarray is the European Central Bank's conference on price and wage setting (ECB 2108). All contributions were characterized by a climate of disorientation: there is full employment and no inflation in sight. Attempts at explanation are hesitant, and even more so are the recommendations.

In his presentation, Charles Wyplosz (2018) notes, for example, that the anticipated inflation rate remains equal to the last year's rate. The inflation target therefore remains 'elusive' but, faute de mieux, 'Inflation targeting remains the best strategy' and 'the interest rate instrument remains a logical instrument'. In short, the mechanisms no longer work, but there are no others. Perhaps we should take the final Wyplosz's recommendation literally: avoid 'too much preoccupation with markets or "experts"'.

Another contribution (Coibion et al. 2018) is based on the observation that the nominal interest rate is locked at zero lower bound and that inflation remains low. To boost demand, the solution would then be to raise inflation expectations, so as to lower the perceived real interest rate, the one on which agents' decisions are based. It would then be a matter of 'manipulating' expectations, by means of appropriate communication: 'For example, if inflation is too low, emphasize the inflation target (rather than actual inflation) to raise inflation expectations'. This is a proposal that sums up the profound dogmatism of the dominant economy: if there is no trace of our theory in the real world, we shall communicate to make it happen.

\section{CONCLUSION}

This brief review shows that the entire dominant macroeconomics is being shaken in its foundations. But this observation should lead to optimism: indeed, it puts two important ideas back at the heart of the debate. The first is that if monetary policy has lost its effectiveness, it becomes necessary to consider expansionary fiscal policies, giving priority to the ecological transition investments (a Green New Deal). The other idea is Job Guarantee's one, which is inspired by the already mentioned Keynes' strong proposal: 'There is work to do; there are men to do it. Why not bring them together?'. It is around these two combined ideas that a new macroeconomics for the 21 st century could be rebuilt. 
FUNDING: This research received no external funding.

CONFLICT OF INTEREST: The author declares no conflict of interest.

\section{REFERENCES}

Artus, Patrick. 2017. “On ne sait plus analyser la situation à long terme des économies.” Flash Economie, 7 décembre. Paris: Natixis.

Artus, Patrick. 2018a. “La courbe de Phillips est à l'envers”. Flash Economie, 8 janvier. Paris: Natixis.

Artus, Patrick. 2018b. “Ne pas oublier que l'inflation apparaît quand la profitabilité des entreprises est inférieure au niveau souhaité". Flash Economie, 10 avril. Paris: Natixis.

Artus, Patrick. 2018c. "Va-t-il falloir changer complètement la théorie qui sous-tend la politique monétaire de la zone euro?” Flash Economie, 24 mai. Paris: Natixis.

Berson, Clémence et al. 2018. “Does the Phillips curve still exist”. Rue de la Banque $n^{\circ}$ 56, february. Paris: Banque de France.

Beveridge, William. 1942. Social Insurance and Allied Services. London: His Majesty's Srationery Office.

Beveridge, William. 1944. Full Employment in a Free Society. London: George Allen \& Unwin.

Beveridge, William. 1909. Unemployment. A Problem of Industry. London: Green \& Co.

Blanchard, Olivier. 2016. “The Phillips Curve: Back to the '60s?” American Economic Review 106(5): 31-34. DOI: 10.1257/aer.p20161003

Blaug, Mark. 1980. The methodology of economics. Cambridge: Cambridge University Press.

Bremer, William. 1975. "Along the "American Way": The New Deal's Work Relief Programs for the Unemployed.” The Journal of American History 62(3): 636-652. DOI: $10.2307 / 2936218$

Cordemans, Naïm and Joris Wauters. 2018. “Inflation et activité économique sont-elles mal synchronisées dans la zone euro?” Revue économique de la Banque Nationale de Belgique, juin 2018. Brussels: Banque Nationale de Belgique.

Davies, Gavyn. 2017. “The (non) disappearing Phillips Curve: why it matters.” Financial Times October 22. Retrieved September 05, 2019 (https://www.ft.com/content/e1d27c20-b34d-339e-a15f-21f1b3d87857).

ECB. 2018. "Price and wage-setting in advanced economies." ECB Forum on Central Banking 1006. Sintra, 18-20 June.

Friedman, Milton. 1968. “The Role of Monetary Policy.” The American Economic Review 58(1): $1-17$.

Friedman, Milton. 1977. “Nobel Lecture: Inflation and Unemployment.” The Journal of Political Economy 85(3): 451-472.

Galbraith, James K. 1997. “Time to Ditch the NAIRU.” Journal of Economic Perspectives 11(1): 93-108.

Gayon, Vincent. 2017. “Le keynésianisme international se débat. Sens de l'acceptable et tournant néolibéral à l'OCDE.” Annales Histoire, Sciences sociales 72(1): 123- 
164.

Hobson, John.1899. Problems of Poverty. An Inquiry into the Industrial Condition of the Poor. London: Methuen \& Co.

Hopkins, Harry L. 1936. Untitled address, March 14. United Neighborhood Houses Papers, The Social Welfare History Archives, University of Minnesota.

Husson, Michel. 2018a. "Des lois anglaises sur les pauvres à la dénonciation moderne de l'assistanat (II).” A l'encontre, 7 avril. Retrieved September 05, 2019 (http:// alencontre.org/societe/des-lois-anglaises-sur-les-pauvres-a-la-denonciationmoderne-de-lassistanat-ii.html).

Husson, Michel. 2018b. "Phillips (l'inventeur de la courbe): une trajectoire hors du commun.” note hussonet 121, 3 juillet. Retrieved September 05, 2019 (http://hussonet.free.fr/phillips718.pdf).

IMF. 2017. "Recent Wage Dynamics in Advanced Economics: Drivers and Implications.” World Economic Outlook, October 2017. Retrieved September 05, 2019 (http://pinguet.free.fr/weochap2.pdf).

Keynes, John M. and John H. Henderson. 1929. Can Lloyd George Do It? An Examination of the Liberal Pledge. London: The Nation and Athenaeum.

Keynes, John M. 1936. The General Theory of Employment, Interest and Money. Cambridge: Cambridge University Press.

Layard, Richard, Stephen Nickell, and Richard Jackman. 1991. Unemployment. Macroeconomic Performance and the Labour Market. Oxford: Oxford University Press.

Lipsey, Richard. 1960. "The Relation between Unemployment and the Rate of Change of Money Wage Rates: A Further Analysis.” Economica 27(105): 1-31.

Lucas, Robert E. 1978. “Unemployment Policy.” The American Economic Review 68(2): 353-357.

Lucas, Robert E. 1979. “OECD’s McCracken Report. A Review.” Carnegie-Rochester Conference Series on Public Policy 11(1): 161-168.

Marshall, Alfred. 1903. “Letter to Percy Alden.” Pp. 446-447 in Memorials of Alfred Marshall, edited by Arthur C. Pigou. London: MacMillan and Co. 1925.

Marx, Karl. 1976. Capital. Book I. Harmondsworth, Middlesex, England: Penguin Books Ltd.

McCracken, Paul, ed. 1977. Towards full employment and price stability: a report to the OECD by a group of independent experts. Paris: OECD Publishing.

McLeay, Michael and Silvana Tenreyro. 2018. "Optimal Inflation and the Identification of the Phillips Curve." Vox, 3 July.

Modigliani, Franco and Lucas Papademos. 1975. "Targets for Monetary Policy in the Coming Year.” Brookings Papers on Economic Activity 1975(1): 141-165.

OECD. 2018. Rising employment overshadowed by unprecedented wage stagnation. July. Paris: OECD Publishing.

Phillips, Alban W. H. 1958. "The Relation Between Unemployment and the Rate of Change of Money Wage Rates in the United Kingdom, 1861-1957.” Economica 25(100): 283-299.

Pigou, Arthur C. 1913. Unemployment. London: Williams \& Norgate.

Rubin, Goulven. 2012. “Robert Solow de la courbe de Phillips à la question des fonde- 
ments de la macroéconomie: 1960-1981.” Paris: HAL, archives ouvertes.

Samuelson, Paul A. and Robert M. Solow. 1960. "Analytical Aspects of Anti-Inflation Policy.” The American Economic Review 50(2): 177-194.

Sargent, Thomas, Noah Williams, and Tao Zha. 2006. "Shocks and Government Beliefs: The Rise and Fall of American Inflation." The American Economic Review 96(4): 1193-1224.

Schwarzer, Johannes. 2015. Price Stability versus Full Employment: The Phillips Curve Dilemma Reconsidered. Dissertation. Fakultät Wirtschafts- und Sozialwissenschaften der Universität Hohenheim, am 4 Dezember.

Solow, Robert M. 1978. "Summary and Evaluation.” Pp. 203-209 in After the Phillips Curve: Persistence of High Inflation and High Unemployment. Boston: The Boston Federal Reserve Bank.

Solow, Robert M. 1979. “What We Know and Don’t Know About Inflation.” Technology Review 81(3): 30-44.

Tcherneva, Pavlina R. 2012. "Permanent On-The-Spot Job Creation. The Missing Keynes Plan for Full Employment and Economic Transformation." Review of Social Economy 70(1): 57-80. https://doi.org/10.1080/00346764.2011.577348

The Economist. 2018. "If wages are to rise, workers need more bargaining power." May 31st.

Tobin, James. 1972. "Inflation and Unemployment.” The American Economic Review 62(1/2): 1-18.

\section{BIOGRAPHICAL NOTE}

Michel Husson is professor of economics at the Institut de Recherches Economiques et Sociales, France.

OPEN ACCESS: This article is distributed under the terms of the Creative Commons Attribution Non-commercial License (CC BY-NC 4.0) which permits any non-commercial use, and reproduction in any medium, provided the original author(s) and source are credited. 
